University of Warwick institutional repository

This paper is made available online in accordance with

publisher policies. Please scroll down to view the document itself. Please refer to the repository record for this item and our policy information available from the repository home page for further information.

To see the final version of this paper please visit the publisher's website. Access to the published version may require a subscription.

Author(s): KATHARINE GELBER AND MATT MCDONALD

Article Title: Ethics and exclusion: representations of sovereignty in Australia's approach to

asylum-seekers

Year of publication: 2006

Link to published version:

http://dx.doi.org/10.1017/S0260210506007029

Publisher statement: None 


\title{
Ethics and exclusion: representations of sovereignty in A ustralia's approach to asylum-seekers
}

\author{
KATHARINE GELBER AND MATT MCDONALD*
}

A bstract. From 2001, the A ustralian government has justified a hard-line approach to asylum-seekers on the basis of the need to preserve its sovereignty. This article critically evaluates this justification, arguing that the conception of sovereignty as the 'right to exclude' involves a denial of responsibility to the most vulnerable in global politics. We particularly focus here on the ways in which the A ustralian government has attempted to create support for this conception of sovereignty and ethical responsibility at the domestic level, through marginalising alternative voices and emphasising the 'otherness' of asylum-seekers and refugees. W e conclude by suggesting what this might mean for the treatment of asylum-seekers in global politics and for statist approaches to global ethics.

The protection of our sovereignty, including A ustralia's sovereign right to determine who shall enter A ustralia, is a matter for the A ustralian government and this parliament. ${ }^{1}$

A ustralian M inister for Immigration, Phillip R uddock, 2001.

F rom A ugust 2001, when the A ustralian military intercepted a vessel carrying over 400 asylum-seekers and refused to allow it entry to A ustralia, A ustralia's approach to asylum-seekers has been a particularly prominent issue in political debate. The A ustralian government's approach has elicited a strong response both domestically and internationally and has even been attributed with the re-election of the conservative $\mathrm{H}$ oward government in 2001. We argue in this article that the A ustralian government has represented an approach to asylum-seekers consistent with international human rights norms as being mutually exclusive with the preservation of national sovereignty. Ultimately, the government has defined sovereignty as the 'right to exclude', a conception of sovereignty consistent with pluralist English School accounts of the normative basis of international society but with disturbing implications for the treatment of asylum-seekers in that international society.

In this article we address three central questions. First, how has the A ustralian government defined sovereignty regarding asylum-seekers? Second, how has this

\footnotetext{
* The research for this article was partially funded by a grant from the F aculty of A rts and Social Sciences, U N SW. We would like to thank Susannah H elman for her exceptional research assistance, and A lex Bellamy, Cindy O'H agan, David A rmstrong and the three anonymous reviewers for their helpful comments on an earlier draft of this article.

1 Phillip Ruddock, House of Representatives Hansard, 18 September 2001, pp. 30869-72.
} 
conception of sovereignty 'won out' over alternative visions of political autonomy and ethical responsibility? And third, what implications does such a conception of sovereignty have for the treatment of refugees and asylum-seekers in global politics? This article illustrates how the A ustralian government has gone about representing sovereignty, and constructing support for this conception of sovereignty, in such a way as to deny ethical responsibility to asylum-seekers in the face of both international and domestic criticism of its actions. We argue that there is nothing inevitable about conceiving of sovereignty in such terms: rather, this particular conception of sovereignty reflects a series of choices on the part of the A ustralian government, choices that have potentially crucial implications for the treatment of asylum-seekers in global politics. If accepted as legitimate, the conception of sovereignty as the 'right to exclude' would undermine the rights and thereby the wellbeing of those (refugees and asylum-seekers) who do not enjoy the protection of states in international society.

This article therefore provides an empirical analysis of discursive representations of sovereignty in the Australian context, reflects on the implications of such representations for asylum-seekers in international society, and links this analysis to broader issues regarding the relationship between sovereignty and human rights and the boundaries of ethical responsibility in global politics. The article proceeds in four parts. F irst, we outline how we understand sovereignty and its relationship to human rights, and discuss the ethical implications of alternative visions of the sovereigntyhuman rights relationship. Second, we provide a brief overview of the central dimensions of A ustralia's asylum-seeker policies from 2001-03. The third and central section of the article outlines how the Australian government has represented sovereignty in the period in question and gone about constructing support or resonance for this conception in the broader populace. Finally, we briefly reflect on the implications this has for the treatment of asylum-seekers in international society and for statist accounts of global ethics, while also outlining immanent possibilities for the movement towards an alternative conception of sovereignty in the A ustralian context: one guided by a recognition of obligations to vulnerable and suffering outsiders.

\section{Sovereignty and human rights}

Given that the Australian government has represented the preservation of sovereignty as inconsistent with international human rights norms, it is worth reflecting broadly on the (vexed issue of the) relationship between sovereignty and human rights in International R elations (IR). While in global ethics literature this relationship can be characterised as a debate between cosmopolitan and communitarian approaches about the best means of achieving human rights in global politics, in IR literature the sovereignty-human rights relationship has been a particularly prominent issue in English School debates about the normative foundation of international society. For Hedley Bull, the sovereignty-human rights relationship could be understood in the context of 'the inherent tension between the order provided by the system and society of states, and the various aspirations for justice 
that arise in world politics'. ${ }^{2} \mathrm{M}$ ore specifically, Bull argued that the central ordering principle of international society was the preservation of state sovereignty (and hence order), which was the best possibility of allowing for the realisation of individual wellbeing and preserving international society itself. ${ }^{3}$ In a contemporary context, R obert J ackson ${ }^{4}$ has advanced this pluralist argument in warning against a potentially emerging norm of humanitarian intervention. This view (of the primacy of order and the norm of sovereignty defined as non-intervention) is itself arguably based upon the recognition that a central motivation for the establishment of the modern state system and the concomitant principle of sovereignty was to allow for the realisation of individual wellbeing in an otherwise $\mathrm{H}$ obbesian state of nature. ${ }^{5}$

In this (pluralist) account, the relationship between sovereignty and human rights can be defined in one of two ways. First, it might be argued that the necessity of preserving international society means that the preservation of state sovereignty defined as non-intervention should be given priority over human rights norms when the two come into conflict. ${ }^{6}$ A Iternatively, it might be argued that the realisation of human rights requires a commitment to the preservation of sovereignty defined as non-intervention because states are the actors in international society most capable of providing for individual wellbeing. This latter point, reminiscent of Bull's characterisation of the human rights-sovereignty relationship and communitarian approaches to global ethics, ${ }^{7}$ certainly comes closest to the A ustralian government's ethical justifications for its treatment of asylum-seekers, as will be noted.

There are two levels, however, at which the issue of asylum-seekers questions the ethical justifications for sovereignty defined in exclusive terms. F irst, the existence of refugees and asylum-seekers points to the fact that some states are clearly falling short of providing for individual human rights (namely the states from which refugees and asylum-seekers are fleeing). A range of critical scholars of international relations invoke this argument (the potential disjuncture between the state as means and ends) as the basis for calling for alternative conceptions of security and sovereignty in international relations. ${ }^{8}$ Second, and more fundamental to this article, sovereignty defined as the right to exclude provides us with little basis for recognising and addressing the needs of those who are stateless and are therefore without the type of protection envisaged by pluralists and communitarians. This point is central to the ethical and normative problems we have with the Australian government's conceptualisation of sovereignty, to which we will return later.

2 Hedley Bull, The Anarchical Society: A Study of Order in World Politics (L ondon: M acmillan, 1995), p. 83, our emphasis.

${ }^{3}$ Although it should be noted that Bull did acknowledge the possibility that concerns of justice could, in the future, 'win out' over concerns of the preservation of order within international society. Bull, The Anarchical Society, pp. 74-94.

4 R obert Jackson, Quasi-States: Sovereignty, International Relations and the Third World (Cambridge: Cambridge U niversity Press, 1990).

5 Christian R eus-Smith 'H uman R ights and the Social Construction of Sovereignty', Review of International Studies, 27:4 (2001), pp. 519-38.

6 This point underpins J ackson's rejection of the imperative for intervention in response to humanitarian crises (in Quasi-States, and Robert Jackson, The Global Covenant: Human Conduct in a World of States (Oxford: Oxford U niversity Press, 2000).

7 See, for example, M ichael Walzer, Spheres of Justice (N ew Y ork: Basic Books, 1983).

8 Ken Booth, 'Security and Emancipation', Review of International Studies, 17:2 (2001), pp. 313-26; Bill M CSweeney, Security, Identity and Interests: A Sociology of International Relations (Cambridge: Cambridge U niversity Press, 1999); N icholas W heeler, Saving Strangers: Humanitarian Intervention in International Society (Oxford: Oxford U niversity Press, 2000). 
A point inferred by much of the above is that there are alternative ways of conceiving of sovereignty, and by extension its relationship to human rights. To be sure, sovereignty may be defined as the right of states to non-intervention in domestic affairs, ${ }^{9}$ a definition that while potentially underpinned by ethical and normative considerations, serves to deny ethical responsibility to those outside the territorial borders of the nation-state. This should not be conceived of as the essence of sovereignty in any timeless sense, however. As a growing number of analysts have argued, sovereignty may be defined in such a way as to require a broadening of boundaries of ethical responsibility, even to the point of necessitating a rejection of the inviolability of state borders. ${ }^{10} \mathrm{Clearly}$, these different conceptions of sovereignty have different implications for the treatment of asylum-seekers in international politics. We argue here that sovereignty is ultimately a social construction, the meaning of which changes in different contexts. ${ }^{11}$ Once we acknowledge this, it becomes imperative to investigate how this meaning is constructed and to assess the implications that such a conception has for political practice.

In locating the meaning of sovereignty held by the Australian government regarding its treatment of asylum-seekers, we focus in this article on the discursive representational practices of the government itself. These representations may be viewed as both general indications of the government's beliefs and/or worldview, and as important forms of political action. The critical discourse analysis approach outlined by Norman Fairclough, defined as a theory and method for 'studying language in its relation to power and ideology',12 is particularly relevant to our analysis here. Discursive representations of sovereignty serve to encourage certain policy approaches while marginalising others; prioritise the needs of certain groups while ignoring others; and legitimise certain actors in speaking for particular political communities while silencing others. ${ }^{13}$ As Werner and de Wilde have argued, 'sovereignty .... is a specific form of legitimisation whose reality consists of its being accepted by relevant audiences'. ${ }^{14}$ This conception also raises an important point: that an analysis of the construction of sovereignty requires an analysis of both the representation and acceptance of particular conceptions of sovereignty. We therefore also address the means through which this conception of sovereignty has come to prominence in the A ustralian context. To this end, we assess the extent of support for the government's approach to asylum-seekers, and particularly reflect on the ways in which the government has attempted to construct its conception of sovereignty,

${ }^{9}$ Such a conception is evident in a range of definitions of sovereignty in international relations, including negative (J ackson, Quasi States, pp. 27-9), external (Bull, The Anarchical Society, pp. 16-17), juridical (Samuel M akinda, 'The U nited N ations and State Sovereignty: M echanisms for M anaging International Security', Australian Journal of Political Science, 33:1 (1998), p. 104) or W estphalian sovereignty (Stephen K rasner, Sovereignty: Organized Hypocrisy (Princeton, N J : Princeton U niversity Press,1999), pp. 3-4).

10 Such a conception of sovereignty is particularly apparent in the work of proponents of humanitarian intervention. F or example W heeler, Saving Strangers; A lex J. Bellamy, 'H umanitarian Intervention and International Society', Review of International Studies, 29:3 (2003), pp. 321-40.

${ }^{11}$ On this point, see J ens Bartelsen, A Genealogy of Sovereignty (Cambridge: Cambridge U niversity Press, 1995).

12 N orman Fairclough, Critical Discourse Analysis: The Critical Study of Language (London: Longman, 1995), p. 1.

${ }^{13}$ On this point see R. B. J. Walker, Inside/Outside: International Relations as Political Theory (Cambridge: Cambridge U niversity Press, 1993), pp. 159-83.

14 W outer W erner and J aap de Wilde, 'The Endurance of Sovereignty', European Journal of International Relations, 7:3 (2001), p. 302. 
human rights and ethical responsibility as legitimate or even desirable. This has been particularly prominent in its willingness to marginalise actors seeking to contest the government's conception of sovereignty (regarding asylum-seekers) as the 'right to exclude'.

Our problem with the government's conception of sovereignty regarding asylumseekers goes beyond misgivings about the means through which the Australian government has attempted to silence or marginalise alternative voices that have characterised A ustralian obligations differently, however. As a number of commentators have argued, sovereignty defined as the 'right to exclude' is inconsistent with the specific requirements of a range of international conventions to which A ustralia is a signatory. ${ }^{15} \mathrm{M}$ ore importantly this conception of sovereignty can be (and we argue has been in the A ustralian case) inconsistent with a basic humanitarian ethic which dictates that 'there is a duty incumbent upon each and every individual to assist those in great distress or suffering when the costs of doing so are low'. ${ }^{16}$ To be sure, the Australian government has emphasised its humanitarian credentials and particularly the costs of admitting asylum-seekers arriving by boat (most insidiously through pointing to the different values of asylum-seekers). It is difficult, however, to accept that the costs of allowing entry to asylum-seekers in terms of national cohesion or the preservation of Australian values could be so great as to warrant the denial of assistance, particularly given that the modern A ustralian state was founded on (and continues to encourage) immigration. It is also difficult to reconcile the above principles of humanitarianism with an approach to asylumseekers that has involved a far greater financial burden than that undertaken by states with more welcoming asylum-policies, and that has even involved an increase in the suffering of asylum-seekers, particularly through the policy of mandatory detention. ${ }^{17}$

Sovereignty understood and approached as the 'right to exclude' regarding asylum-seekers is, therefore, inconsistent with the global human rights regime that states such as Australia have committed themselves to, and is inconsistent with a humanitarian ethic in dealing with suffering outsiders that states such as A ustralia should commit themselves to. While a theory of duties to strangers is clearly beyond the scope of this article, our (broadly) cosmopolitan conception of political community ${ }^{18}$ underpins the desire to problematise the ways in which the Australian government has sought to reject the claims of outsiders through drawing boundaries of ethical obligation at (or indeed outside) the territorial borders of the A ustralian

15 William M aley, for example, argues that when A ustralia acceded to the 1954 Convention R elating to the Status of R efugees, 'it relinquished as a sovereign act any absolute control over who could enter the country and under what circumstances'. W illiam M aley, 'A sylum-Seekers in A ustralia's International R elations', Australian Journal of International Affairs, 57:1 (2003), p. 189.

16 M. G ibney, 'L iberal D emocratic States and R esponsibilities to R efugees', American Political Science Review, 93:1 (1999), p. 178.

17 On these points, see D on M CM aster, 'A sylum-Seekers and the Insecurity of a N ation', Australian Journal of International Affairs, 56:2 (2002), pp. 279-90. The increase in suffering of asylum-seekers is particularly apparent in the context of the mental health implications of long periods in detention centres, particularly for children. On this point, see M itchell Smith, 'A sylum-Seekers in A ustralia', Medical Journal of Australia, 175 (2001), pp. 587-9.

18 On this point, see A ndrew Linklater, The Transformation of Political Community (Cambridge: Polity, 1998), p. 206). For a discussion of partial and impartial approaches to the obligations of liberal democratic states to refugees and asylum-seekers, see G ibney, 'L iberal D emocratic States'. 
state. Its conception and representation of sovereignty have been central to this political project.

\section{Interception and incarceration: A ustralia's approach to asylum-seekers}

W hile the A ustralian government has historically had a troubled approach towards asylum-seekers and immigrants, ${ }^{19}$ arguably the first few years of the new century saw the development of a particularly stark policy. This can be encapsulated and symbolised by the two events which frame the analysis in this article: the Tampa and Minasa Bone incidents. The first occurred in late A ugust 2001, when a N orwegian freighter called the Tampa was asked by the A ustralian government to rescue over 400 asylum-seekers whose boat was sinking in international waters, but was then prevented from entering Australia's migration zone. Australian SAS navy forces subsequently boarded the ship and the asylum-seekers were sent to Pacific Island nations for the processing of their claims. Subsequently the A ustralian government legislated to toughen migration laws regarding asylum-seekers in several ways, including by excising several islands from A ustralia's migration zone. ${ }^{20}$

The second incident occurred in N ovember 2003, when a boat called the Minasa Bone carrying $14 \mathrm{~K}$ urdish asylum-seekers ran aground on M elville island, $80 \mathrm{~km}$ from A ustralia's northern coast. While the asylum-seekers remained on their boat awaiting assistance, the A ustralian federal government gazetted retrospective regulations to remove $\mathrm{M}$ elville and up to 4000 more islands from A ustralia's migration zone. The excision became effective 12 hours before the vessel was first sighted by $M$ elville Islanders ${ }^{21}$ and the boat was towed back into international waters and made its way to Indonesia. 22

The excisions of A ustralian territories from the migration zone followed earlier legislative and policy changes designed to make it more difficult for asylum-seekers to lodge claims for refugee status in A ustralia. These have included the mandatory detention of unauthorised arrivals (including children), first undertaken by the federal Labor government in 1989;23 the reduction of opportunities for judicial review of decisions about asylum status taken by the D epartment of I mmigration;24 the ability to draw adverse inferences from asylum-seekers' lack of identity documents; ${ }^{25}$ and the introduction of a category of temporary (three-year) protection visas

19 On A ustralia's historical fear of (particularly A sian) immigration, see D on M cM aster, Asylum Seekers: Australia's Response to Refugees (M elbourne: M elbourne U niversity Press, 2001).

${ }^{20} \mathrm{~K}$ atharine G elber, 'A F air Queue? A ustralian Public D iscourse on R efugees and Immigration', Journal of Australian Studies, 77 (2003), p. 29.

21 Sophie M orris, 'N ew Bid to R epel A sylum Seekers', The Australian, 5 N ovember 2003, pp. 1, 6.

22 This created a diplomatic furore, with an Indonesian Immigration D epartment spokesperson arguing that A ustralia was treating Indonesia like a 'trash bin'. K imina L yall; Sophie M orris and M arianne K earney, 'N ot $Y$ our Trash Bin', The Australian, 13 N ovember 2003, p. 1 . When parliament reconvened on $24 \mathrm{~N}$ ovember the regulations were disallowed by the Senate: M ark Phillips, '4000 islands put back on the map', Herald-Sun, 25 N ovember (2003), p. 2.

23 M cM aster, Asylum Seekers, p. 67.

24 J ean-Pierre F onteyne, 'Illegal R efugees or Illegal Policy?', in Refugees and the Myth of the Borderless World (Canberra: R SPA S, A ustralian N ational U niversity, 2002), p. 20.

25 G elber, 'A F air Queue?', p. 29; M inister for Immigration, M ulticultural and Indigenous A ffairs, M edia R elease: Australia's Border Integrity Strengthened by New Legislation, M PS164/2001, 26 September 2001, 〈http://www.minister.immi.gov.au/media_releases/ruddock_media01/r01164.htm〉. 
for asylum seekers who made successful onshore claims for refugee status. As introduced, the temporary nature of the visa - every three years the applicant had to reapply for another temporary visa - prevented them from settling permanently in A ustralia. 26

This policy towards asylum-seekers arguably contravenes international law including the United Nations Convention and Protocol Relating to the Status of R efugees, ${ }^{27}$ to which Australia is a signatory, and amounts to a denial of the humanitarian imperative of responding to the immediate suffering of vulnerable outsiders. It also sets a precedent for the abrogation of responsibility towards asylum-seekers on the part of developed, liberal-democratic states. ${ }^{28}$ These points are important to note in considering the normative basis of international society generally, but also (for the purposes of this article) when considering the relationship between these policies and a particular conception of sovereignty that is beginning to define approaches to asylum-seekers in much of the developed world.

The A ustralian government has been subjected to harsh criticism internationally and domestically for its treatment of those asylum-seekers who had gained entry to A ustralia. The head of the UN Working Group on A rbitrary Detention, Justice L ouis J oinet, noted following a visit in 2002 that criminals were treated better than asylum-seekers given the ind efiniteness of the latter's detention, ${ }^{29}$ and that A ustralia's policies amounted to the grossest abuse of human rights he had seen in mandatory detention facilities anywhere in the world. ${ }^{30}$ J ustice Bhagwati, UN regional advisor to the $\mathrm{H}$ igh Commissioner for $\mathrm{H}$ uman Rights, described the mandatory detention of children as contrary to international standards and law. ${ }^{31}$ Domestically, the A ustralian government's policies have been heavily criticised by refugee advocacy groups and the Human R ights and Equal Opportunity Commission, which tabled a report in federal parliament that recommended the immediate release of children from detention. 32

The A ustralian government has responded defensively to U nited Nations' criticism of its domestic policies on human rights grounds, including by arguing that the

${ }^{26}$ D epartment of Immigration, M ulticultural and Indigenous A ffairs [D I M IA ], F act Sheet 64:

Temporary Protection Visas, 2003, 〈http://www.dimia.gov.au/facts/64protection.htm〉. In A ugust

2004 the system of temporary protection visas was modified slightly to allow some asylum-seekers

to apply for permanent visa categories after their initial temporary protection visa had expired:

D epartment of Immigration, M ulticultural and Indigenous A ffairs [CIM IA ], Measures for

Temporary Protection and Temporary Humanitarian Visa Holders 2004, 〈http://www.dimia.gov.au/ refugee/tpv_thv/index.htm $\rangle$.

27 F onteyne, 'Illlegal R efugees', pp. 18; 20-21.

$28 \mathrm{M}$ aley, 'A sylum-Seekers', p. 187.

29 M ichael M illett \& M ichael Bradley, 'Criminals 'better off' than asylum seekers', Sydney Morning Herald, 7 J une 2002, p. 2.

30 M ichael M illett, 'W orst I've seen says U N asylum centre inspector', Sydney Morning Herald, 6 J une 2002, p. 1.

31 Cynthia Banham, 'UN deplores "tragedy" of asylum system', Sydney Morning Herald, 1 A ugust 2002, p. 1. F or further examination of U nited N ations' criticisms of A ustralia's policies towards asylum-seekers and on other grounds deemed racially discriminatory, see D avid K inley and Penny $\mathrm{M}$ artin, 'International H uman R ights L aw at Home: Addressing the Politics of D enial', Melbourne University Law Review, 26 (2002), pp. 469-70. F or more general criticism of A ustralia's compliance with the terms of international human rights treaties see Elizabeth Evatt, 'H ow A ustralia "Supports" the U nited N ations H uman R ights Treaty System: Comment', Public Law Review, 12 (2001), pp. 3-8.

32 H uman Rights and Equal Opportunity Commission [HREOC], 2004, A Last Resort? Report of the National Inquiry into Children in Immigration Detention (Sydney: H R E OC, 2004), 〈http://www.hreoc.gov.au//human_rights/children_detention_report/index.html〉. 
$\mathrm{U}$ nited $\mathrm{N}$ ations should focus its efforts on those countries where egregious breaches of human rights occur, rather than on the A ustralian issues they had commented on which were matters for 'domestic political debate'. ${ }^{33}$ A ustralia's chair of the Parliamentary Treaties Committee reportedly described the $\mathrm{U}$ nited $\mathrm{N}$ ations as a 'theme park for indulging the fantasies of the global NGO movement - heaping abuse on gold plated democracies like A ustralia'. ${ }^{34}$

In addition to these comments, the Australian government has in recent years pursued a selective and conditional engagement with the international multilateral human rights treaty system. In conjunction with the criticisms raised by the A ustralian government towards comments by UN representatives, A ustralia announced that it would henceforth adopt a more 'strategic' approach to interaction with the UN treaty committee system, and a 'selective' approach to reporting to committees where 'appropriate'. 35 F oreign policy developments such as these have been underpinned by a broader set of assumptions and commitments on the part of the A ustralian government in defining the national interest and approaching global politics. Centrally, these have involved an increased scepticism of international rules, norms and institutions; an emphasis on bilateralism and traditional strategic relationships with powerful states such as the US; and ultimately an emphasis on a foreign policy characterised by a narrowly defined national interest rather than 'unrealistic notions of global idealism'36 that had, according to the conservative government, informed the previous government's commitment to 'good international citizenship'. ${ }^{37}$ This general foreign policy orientation provides important context to the government's conception of A ustralian sovereignty regarding asylum-seekers.

\section{Sovereignty: ethics and exclusion}

\section{Characterisations of sovereignty}

In addressing the question of asylum-seekers from the 2001 Tampa crisis to the Minasa Bone incident in 2003, the A ustralian government consistently defined its approach as being underpinned by a concern for the preservation of Australia's sovereignty. In doing so the A ustralian government defined sovereignty ultimately as

${ }^{33}$ A lexander Downer, Interview on ABC 7.30 Report: Government to Review Participation in UN Treaty Committee System, 30 M arch 2000; K inley and M artin, 'International H uman R ights L aw', p. 468.

34 R obert Garran, 'N o need for U N's help - PM', The Australian, 31 A ugust 2000, p. 2.

35 A lexander D owner, House of Representatives Hansard, 18 J une 2000, p. 3606; A lexander D owner, $\mathrm{N}$ ational Press Club Speech: Advancing the National Interest: Australia's Foreign Policy Challenge, 7 M ay 2000, 〈http://www.foreignminister.gov.au/speeches/2002/020507_fa_whitepaper.html〉.

36 D epartment of F oreign A ffairs and Trade, cited in David Goldsworthy, 'A n Overview', in Cotton and Ravenhill (eds.), The National Interest in a Global Era: Australia in World Affairs 1996-2000 (M elbourne: Oxford U niversity Press, 2001), p. 11.

37 On 'good international citizenship' see A ndrew L inklater, 'W hat is a Good International Citizen', in Paul K eal (ed.), Ethics and Foreign Policy (St Leonards: Allen and U nwin, 1992). On broader trends in A ustralian foreign policy under the conservative $\mathrm{H}$ oward government, see for example Goldsworthy, 'A n Overview'; J oseph Camilleri, 'A L eap Into the Past - In the N ame of the N ational Interest', Australian Journal of International Affairs, 57:3 (2003), pp. 431-53; and M att M CD onald, 'C onstructing Insecurity: A ustralian Security D iscourse and Policy Post-2001', International Relations, 19:3 (2005), pp. 297-320. 
the right to exclude. There are two crucial dimensions of this conception of sovereignty, evidenced in a range of representations to be noted below. First, sovereignty is represented as a right or norm of international society rather than as an empirical fact, the latter being more consistent with Stephen $\mathrm{K}$ rasner's definition of Westphalian sovereignty. ${ }^{38}$ Second, sovereignty is represented as being exclusive with external forms of influence or involvement in domestic political affairs. F undamentally, the Howard government's conception of sovereignty is a pluralist English School one, emphasising the imperative of non-intervention in domestic affairs, extending to the 'absolute right of the (A ustralian) government to determine who will enter the country and under what circumstances'. 39 Indeed, as Robert J ackson has argued, 'non-intervention and sovereignty in this meaning are basically two sides of the same coin'. ${ }^{40}$ In terms of an ethical framework, the consistency of this conceptualisation of sovereignty with communitarian approaches is also particularly apparent: the 'right to exclude' is the terminology Peter Carens uses in characterising $M$ ichael Walzer's communitarian account of states' obligations to refugees and asylum-seekers. ${ }^{41}$

The A ustralian government's invocation of sovereignty regarding its treatment of asylum-seekers was most pronounced in response to the issue of border control, when A ustralia's sovereignty (defined in terms of its territorial integrity) was represented as being 'threatened' by the unauthorised arrival of boatloads of asylum-seekers. ${ }^{42}$ Indeed, the imperative of preserving Australian sovereignty was represented as providing the central rationale for A ustralia's response to the Tampa crisis. Foreign $M$ inister D owner argued that 'at the heart of this (the Tampa issue) is the protection of our territorial integrity'. ${ }^{43}$ Then leader of the government in the Senate, Senator $\mathrm{R}$ obert $\mathrm{H}$ ill, noted that the protection of A ustralian 'sovereignty . . . to put in place measures to protect A ustralia's borders ... (was) the key issue' in Australia's approach to the Tampa crisis. ${ }^{44}$ A nother government member of Parliament argued that 'this [T ampa] has everything to do with national sovereignty'. ${ }^{45}$ In short, then, an analysis of the representation of sovereignty is critical here precisely because 'sovereignty' was the basis upon which the A ustralian government defined its actions.

The central pillar of the Australian government's discursive construction of sovereignty regarding asylum-seekers, particularly concerning border control, was the oft-expressed 'right' of A ustralia to decide, as Prime $\mathrm{M}$ inister $\mathrm{H}$ oward first put it, 'who comes here and the circumstances in which they will come'. ${ }^{46}$ In many ways, this became the government's mantra regarding its approach to border control and asylum-seekers. The Prime $\mathrm{M}$ inister reiterated this concern in almost identical

38 K rasner, Sovereignty, pp. 20-5.

39 M aley, 'A sylum-Seekers', p. 188.

40 Jackson, The Global Covenant, p. 27.

41 Peter Carens, 'A liens and Citizens: The Case for Open Borders', Review of Politics, 49:2 (1987), p. 266.

42 There were also important representations of sovereignty regarding international criticism of mandatory detention policies, however for the most part representations of sovereignty regarding asylum-seekers centred on the question of border control.

43 In A nthony Burke, In Fear of Security: Australia's Invasion Anxiety (Sydney: Pluto, 2001), p. 322.

44 R obert Hill, Senate Hansard, 30 A ugust 2001, p. 27090.

45 G ary Hardgrave, House of Representatives Hansard, 30 A ugust 2001, p. 30703.

46 J ohn H oward, Interview with Alan Jones, Radio 2 UE, 30 A ugust 2001, 〈http://www.pm.gov.au/news/ interviews/2001/interview1199.htm〉. 
language on a number of occasions in subsequent weeks and months, ${ }^{47}$ while F oreign M inister Downer and Immigration M inister Philip R uddock noted that it was the 'sovereign right of Australia to determine who will enter its borders and the circumstances of that entry'. 48

This conceptualisation was itself based on a broader argument: that the control of a state's borders generally was an issue for that state alone. Prime M inister H oward argued that allowing boats carrying asylum-seekers to reach Australia would undermine 'A ustralia's control over its sovereign territory', ${ }^{49}$ and that:

Every country has a right to refuse entry to the vessel of another country of course. It's fundamental to a nation's sovereignty, a nation's control of its borders. ${ }^{50}$

This idea was reiterated by other members of the government. Immigration M inister R uddock said, 'it is clearly up to A ustralia to determine who can cross our borders ...',51 and the Coalition government's immigration policy statement in the lead up to the federal election in 2001 stated that:

The Coalition maintains that it is the sovereign right of any nation to determine who does and who does not enter its borders for temporary or permanent stay. ${ }^{52}$

Border integrity and sovereignty were invoked simultaneously and interchangeably to justify the rejection of A ustralia's obligation to process the claims of asylumseekers arriving by boat. In mid-2002, the I mmigration and F oreign A ffairs M inisters and the Attorney-General also applied this understanding of sovereignty to the government's controversial policy of mandatory detention, arguing that 'immigration detention is an essential element underpinning the integrity of Australia's migration program and the protection of our borders'.53

The government's frequent invocations of sovereignty as border integrity (in relation to asylum-seekers) from 2001-03 therefore consistently and overwhelmingly positioned 'sovereignty' on the one hand, and a more humane approach to asylum-seekers on the other, as mutually exclusive. Perhaps more significantly in terms of the meaning of sovereignty communicated, such an approach was defined in normative terms. The definition of sovereignty as a 'right' of states in an international society was most telling in this context. Prime M inister Howard noted in the days following the blockade of the Tampa that 'the protection of our sovereignty, including Australia's sovereign right to determine who shall enter Australia, is a

47 J ohn Howard, Interview with Kerri-Anne Kennerley, Radio 2GB, 1 N ovember 2001, 〈http://www.pm.gov.au/news/interviews/2001/interview1434.htm〉; H oward cited in Fran K elly, $A B C$ TV 7.30 Report Tampa Retrospective, 26 A ugust 2002, 〈http://www.abc.net.au/7.30/content/2002/ s659178.htm〉.

48 A lexander D owner and Phillip R uddock, J oint M edia R elease: Government Rejects UN Report on Arbitrary Detention, FA 184, 13 D ecember 2002, 〈http://www.foreignminister.gov.au/releases/2002/ fa184a_02.html>.

49 J ohn Howard, House of Representatives Hansard, 29 A ugust 2001, p. 30569.

50 John Howard, Interview with Jeremy Cordeaux, 5DN, 29 A ugust 2001, 〈http://www.pm.gov.au/ news/interviews/2001/interview1197.htm〉.

51 Phillip Ruddock, House of Representatives Hansard, 18 September 2001, pp. 30869-72.

52 Coalition, The Howard Government: Putting Australia's Interests First, Election 2001: Immigration Policy Statement (2001), p. 13.

53 A lexander Downer, Phillip R uddock and Darryl Williams, Joint Media Release: Government Rejects the Report of the UN Human Rights Commissioner's Envoy into Human Rights and Immigration Detention, F A 109, 31 J uly 2002, 〈http://www.foreignminister.gov.au/releases/2002/ fa109_02_un_hr_report.html $>$. 
matter for the A ustralian government and this parliament'. ${ }^{54}$ I mmigration M inister Philip Ruddock Immigration Minister Philip Ruddock used exactly the same wording to define the government's position three weeks later, 55 while L eader of the government in the Senate, R obert $\mathrm{H}$ ill, argued that 'like every other country in the world, we demand the right to protect our sovereignty'. ${ }^{56}$

This right extended, for the government, beyond the normative basis of international society to the legal basis of international order. Prime M inister Howard evoked juridical sovereignty in arguing that 'I think we have clearly a legal right to defend the integrity of our own border'. ${ }^{57}$ A government Senator, Santo Santoro, argued in 2003 that 'it is wholly unexceptional that a sovereign country should have the absolute right to decide who crosses its borders'. He went further in saying:

We must enforce our national right to determine who comes here to live, and when and how they do so. Let us hear no more of this nonsense that we live in a borderless world or that we owe a greater obligation than the people of other countries to those who would prefer to bend the rules and come to our shores illegally. ${ }^{58}$

This comment positioned sovereignty-as-exclusion as a right of all states, while further denying ethical obligation to those outside A ustralia's borders and rejecting the increasingly common argument that sovereignty defined in exclusive terms is inconsistent with the imperative to address transnational issues such as people movements. 59

W hile it may be superficially appealing to define the government's approach solely as one that sought to deny ethical responsibility, the A ustralian government did discuss ethical obligation in the context of its commitment to A ustralia's domestic population. This conception of ultimate responsibility to domestic populations provides an important foundation (as it does for pluralist approaches to international society) for the presentation of sovereignty and non-intervention as interchangeable. Immigration $\mathrm{M}$ inister R uddock argued that:

The A ustralian public has a clear expectation that A ustralian sovereignty, including in the matter of entry of people to A ustralia, will be protected by this parliament and the government. The A ustralian public expects its government to exert control over our borders $\ldots 60$

Senator Hill argued that 'the community expects us to put in place measures to protect A ustralia's borders', 61 again defining the government's policies and conception of sovereignty as consistent with, if not ultimately derived from, public opinion. Such a representation may be viewed as an attempt to shore up or construct public support rather than simply reflect it, a point relevant to the broader question of how

54 Howard, Hansard, 29 A ugust 2001, p. 30569.

55 Ruddock, Hansard, 18 September 2001, p. 30869.

56 Hill, Senate Hansard, 30 A ugust 2001, p. 27090.

57 Howard, Interview with Alan Jones.

58 Santo Santoro, Senate Hansard, 16 J une 2003, p. 11353.

59 Of course, this representation of the 'nonsense' of arguments regarding the increasingly untenable idea of exclusive sovereignty appears inconsistent with the fact that human rights commitments made by A ustralia, specifically regarding asylum-seekers, already implicitly rejected this conception (Pace, Senate Select Committee) and that the government appeared willing to compromise its sovereignty (defined in exclusive terms) regarding other areas of interdependence sovereignty such as trade, for example (see M aley, 'A sylum-Seekers', p. 189).

60 R uddock, Hansard, 18 September 2001, pp. 30869-72.

61 H ill, Hansard, 30 A ugust 2001, p. 27090. 
this conception of sovereignty came to 'win out' over others in the Australian context. Senator Santoro contended that it was 'our duty as a legislature . . . to make our borders as impermeable as possible . . .'62 Prime M inister H oward invoked both public opinion and A ustralia's national interests in arguing that:

I've got to reflect public opinion but I've also got to defend the national interest and it is clearly not in A ustralia's national interest to continue to be saying to the world, we are an easy target. ${ }^{63}$

The government's ethical defence of its approach to asylum-seekers was that its commitment to exclusive sovereignty was consistent with the ultimate (ethical) responsibility that governments have to their domestic populations. Of course, questions must arise regarding which voices in the domestic context are prioritised or marginalised, and it is far from self-evident that popular policies or sovereignty defined as the right to exclude are necessarily in the national interest. $64 \mathrm{~N}$ evertheless, the government ultimately positioned its ethical responsibility to the domestic population in preserving the integrity of Australia's borders as 'trumping' a more humane treatment of asylum-seekers. This conception of the boundaries of ethical responsibility in foreign policy was captured in a more general sense by Foreign M inister A lexander D owner in 2002:

The Government has a responsibility for the national interest and to fight for the interest of all A ustralians. But we have to be responsive to the values and ethics of the A ustralian people. These are the twin pillars ... upon which I base A ustralian foreign policy. ${ }^{65}$

To reiterate, the government's conception of sovereignty, invoked to deny the claims/entry of asylum-seekers, can be defined as a 'right to exclude'. This conception was presented in such a way as to marginalise alternative accounts of sovereignty, through presenting sovereignty as the 'right to exclude' as a legal and normative right of states in international society and as a manifestation of the ultimate obligations states have to their own citizens. This conception of sovereignty is consistent with a pluralist English School account of sovereignty, wherein sovereignty defined as non-intervention is the sole basis of an international society itself, the best means of realising and preserving individual rights, and where the violation of this norm in the act of prioritising others (universal human rights, for example) could even threaten the foundation of international order. ${ }^{66}$ The consistency of this worldview with the government's general foreign policy orientation was underscored by Foreign $M$ inister Downer's reference to English School theorist Martin Wight, albeit incorrectly identified by Downer as a R ealist. Downer argued in mid-2002 that:

the Government has ensured that A ustralia's national interest is advanced in an ambitious yet pragmatic and clear-minded fashion. Because if we don't ... no one else will. To borrow the words of English realist M artin Wight, 'a foreign minister is chosen and paid to look after the interests of his [sic] country, and not to delegate for the human race'. We are not about trumpeting our own international good citizenry simply for the sake of it. That is

62 Santoro, Hansard, 16 J une 2003, p. 11353.

63 Howard, Interview with Alan Jones.

64 On the A ustralian government's definition of its national interest and in particular on the choices and assumptions made in conceiving of A ustralia's national interests in these ways, see Camilleri, 'A L eap into the Past'.

65 Downer, National Press Club Speech.

66 Bull, The Anarchical Society; Jackson, The Global Covenant. 
a trap for the ideologues and the naïve. We are about good international citizenry where it can be shown to deliver tangible results for our interests and those of other people', ${ }^{67}$

This statement demonstrates not only the consistency of the government's conception of sovereignty regarding asylum-seekers in 2001-03 with its foreign policy worldview, but provides a useful insight into the ways in which ethical responsibility was defined by the Howard government through its representation of sovereignty.

To the extent that the A ustralian government did recognise the need to accept asylum-seekers at all, this was grounded less in the responsibilities of a (wealthy, liberal-democratic) state to uphold core norms and rules of international society than in the values and goodwill of A ustralia and A ustralians. Such engagement with Australian beliefs and values was again an important means through which this conceptualisation of sovereignty and obligation was able to resonate with the Australian population and triumph over competing conceptualisations of sovereignty. Central to this project was the consistent emphasis on A ustralia's strong human rights record. In the days following Tampa, Prime M inister John Howard argued that 'we're trying to balance our legitimate right to preserve our border integrity with our very legitimate concern as a nation that for generations has taken refugees from all around the world'. $68 \mathrm{He}$ also argued that:

this is an awful problem for A ustralia. On the one hand we want to defend our borders, rightly so, on the other hand, we are a decent people, we don't behave in a way that causes people to drown and die, we don't shoot people, we don't carry on in that fashion and it's probably because of that that we are seen by many around the world as a soft touch. ${ }^{69}$

H oward also noted that it was 'monstrously unfair to describe A ustralia as heartless and inhumane', and referred to Australia's 'magnificent refugee record'.70 $\mathrm{M}$ ore fundamentally, he argued that 'we are A ustralian. We don't behave barbarically' ${ }^{71}$ A s such, the government defined its commitment to behaving in a 'decent' manner towards asylum-seekers as arising from its own values rather than being necessitated by the terms of the international human rights regime. Through this characterisation, the A ustralian government was able to maintain its ultimate right to deny consideration to those outside the borders of the A ustralian state. While more progressive than an outright rejection of any and all claims for asylum within A ustralia, such an approach has worrying implications given the prioritisation of the 'right to exclude' over an obligation to assist.

\section{Representations of asylum-seekers}

The attempt to ensure that the government's conceptualisation of sovereignty 'won out' over others (or, more positively, resonated with the A ustralian population) was most evident in the government's representation of asylum-seekers themselves.

67 Downer, National Press Club Speech.

68 John H oward, Interview with Rosemary Church CNN, 31 A ugust 2001, 〈http://www.pm.gov.au/ news/interviews/2001/interview1203.htm〉.

$69 \mathrm{H}$ oward, Interview with Alan Jones.

70 Howard, Ibid.

71 J ohn H oward, Interview with Charles Woolley, 60 Minutes, 2 September 2001, 〈http:// www.pm.gov.au/news/interviews/2001/interview1210.htm〉. 
Indeed, these representations may be viewed as attempts to create a context in which A ustralians viewed asylum-seekers themselves as less worthy of ethical consideration not simply because they came from 'outside', but because their conduct (indeed their humanity) was fundamentally inconsistent with the values of A ustralians. This is an important point to note given, as W alzer argues, that it becomes harder to justify inaction in the face of an outsider's suffering if that individual shares similar beliefs, values or characteristics with the political community concerned. ${ }^{72}$ By extension, a concerted attempt to emphasise difference in values or beliefs becomes a useful means of justifying inaction and even constructing the costs of allowing entry to 'different others' as unacceptably high. The A ustralian government variously (and often) portrayed asylum-seekers as 'illegals', 'queue-jumpers', 'criminals' and 'potential terrorists'. The fact that some of these characterisations were empirically questionable, ${ }^{73}$ while other government claims about asylum-seekers were quite simply fabrications, ${ }^{74}$ demonstrates how far the A ustralian government was willing to go to create support for its conception of sovereignty and associated asylum-seeker policies.

A s soon as the Tampa incident began, Prime M inister Howard began to refer to the illegality of asylum-seekers' actions and to asylum-seekers themselves as 'illegals'. In A ugust 2001, he said allowing the Tampa to enter:

could have led to the illegal entry of the persons on board into A ustralia, thus undermining A ustralia's control over its sovereign territory ... There is no doubt that the integrity of the borders of A ustralia has been under increasing threat from the rising flood of unauthorised arrivals. ${ }^{75}$

These terms, and associated representations of 'queue-jumping', were repeated over the following two days, when the Prime Minister contrasted 'people who are queue-jumping' with 'genuine refugees'76 and when he repeated his differentiation between asylum-seekers who followed 'proper assessment procedures' and those who 'jump their place in the queue' adding:

... we are opposed to a situation where people can force their way to the front of the queue, arrive illegally, and having got to A ustralia in effect push other people out of the way. ${ }^{77}$

The example of 'queue-jumping' provides a particularly useful insight into the ways in which the government sought to represent its asylum-seeker policy in a way that was understandable and amenable to the A ustralian population. Specifically, the idea

72 W alzer, Spheres of Justice, p. 49.

${ }^{73} \mathrm{~F}$ or example, the use of the term 'illegals' prioritises domestic legal constructions of what constitutes authorised arrival. This contradicts A rticle 31 of the UN Convention Relating to the Status of R efugees (to which A ustralia is a signatory), which specifies that there should be no penalty by signatories to the Convention for entry by asylum-seekers without legal authorisation. The use of the term 'queue-jumpers' is also empirically questionable in that it implies the existence of an ordered or legitimate 'queue' for processing of claims for asylum which often does not exist (see G elber, 'A F air Queue?'). Finally, there has been no evidence of terrorists being among those seeking asylum since 2001, and this link has been rejected by a range of analysts: see $M$ ichael M adigan, 'Boat terror links claimed', The Courier-Mail, 20 September 2001, p. 2.

$74 \mathrm{~F}$ or example, in the lead up to the $2001 \mathrm{~F}$ ederal election the D efence M inister Peter R eith claimed to have evidence that asylum-seekers were throwing children overboard, a claim acknowledged by the government (after the election) to have been untrue.

75 Howard, Hansard, 29 A ugust 2001, p. 30569.

76 Howard, Interview with Alan Jones.

77 H oward, Interview with Rosemary Church. 
of egalitarianism has been central to dominant narratives of A ustralian beliefs, identity and values, ${ }^{78}$ and portraying asylum-seekers as behaving in a manner inconsistent with this 'core Australian value' through jumping a queue may be viewed as an attempt to portray asylum-seekers arriving by boat as having values inconsistent with that of A ustralians.

In September the Prime M inister reiterated that the government 'will do everything we can .... to deter people from coming here illegally'79 and he called the asylum-seekers on the Tampa 'illegal immigrants', adding 'if you allow illegal immigration of that type to interrupt the refugee flow you really are allowing those people to go ahead of others' ${ }^{80}$ In October 2001 when the A ustralian government accused asylum-seekers of deliberately throwing their children into the sea to provoke rescue - a charge later revealed to have been fabricated - the Prime M inister said, 'I don't want in A ustralia people who would throw their own children into the sea. I don't. I don't think any A ustralian does. ${ }^{\circ 1} \mathrm{~A}$ gain, such a representation served to position asylum-seekers as acting in ways inconsistent with A ustralian values. The association between asylum-seekers, criminality and dubious character was developed to a further (and arguably absurd) level after the terrorist events of September 11th. Peter Slipper, for example, Parliamentary Secretary to the M inister for A dministration and F inance, stated in an interview on 19 September 2001 that:

there is a connection between illegals and terrorists and we ought to consider that many of the people that claim to be refugees are people who come from A fghanistan ... It's not beyond the realms of possibility that the Taliban regime could well be sending people to A ustralia as terrorists under the guise of illegals. ${ }^{82}$

When A ustralia became subject to external criticism for its policies towards asylum seekers, these themes continued to be iterated. In reply to U nited $\mathrm{N}$ ations' criticisms of mandatory detention, for example, a joint statement by $F$ oreign $M$ inister A lexander Downer, Immigration M inister Ruddock and the Attorney-General $D$ arryl W illiams emphasised their view that 'people in immigration detention have arrived in the country illegally'.83 In an interview in A ugust 2002, F oreign M inister Downer and Trade $M$ inister $M$ ark Vaile repeated:

we want to crack down on illegal immigration ... These people, these political activists on the issue of illegal immigration, are basically trying to break down the capacity of A ustralia to deal with the problem of illegal immigration. ${ }^{84}$

A side from depicting claims for asylum as illegitimate based purely on mode of arrival rather than on the substance of claims to refugee status, these representations amount

\footnotetext{
78 Elaine Thompson, Fair Enough: Egalitarianism in Australia (Sydney: U N SW Press, 1994). A Ithough Thompson argues that while a central component of how A ustralians see themselves and in dominant narratives of national identity, the notion of egalitarianism is not necessarily reflected in either policy or the material distribution of resources.

79 J ohn H oward, Interview at Sydney Airport, 8 September 2001, 〈http://www.pm.gov.au/news/ interviews/2001/interview1223.htm〉.

80 J ohn H oward, Interview with Jim Lehrer, News Hour PBS, Washington DC, 10 September 2001, 〈http://www.pm.gov.au/news/interviews/2001/interview1232.htm〉.

81 In K elly, $A B C T V$.

82 Peter Slipper, Interview with Seven Sunrise Cover Story: The Refugee Crisis, 2 September 2001, 〈http://www.news.com.au/common/story_page/0,4057,2898609\%255E 1702,00.html〉.

83 Downer et al., Joint Media Release FA 109.

84 A lexander D owner and M ark Vaile, Doorstop Interview in Bandar Seri Begawan, Brunei, 1 A ugust 2002, 〈http://www.dfat.gov.au/media/transcripts/2002/20801_fa_malmou_unhchr_aftacer_dprk.html〉.
} 
to a vilification of asylum-seekers by questioning their humanity. Such representations of asylum-seekers are reminiscent of $\mathrm{N}$ eta Crawford's characterisation of 'identity arguments', which 'posit that people of a certain kind act or don't act in certain ways and that the audience of the argument either positively or negatively identifies with the people in question'. 85 Such representations are again important in considering how particular conceptions of sovereignty might be accepted by domestic populations. Opposition M ember of Parliament Carmen Lawrence acknowledged the political functions of these forms of representation in arguing that:

... the government has systematically breached every principle of decency and humanity, judging that there is electoral advantage in vilifying and damaging people who are easily characterised as unlike us and unworthy of our assistance. 'Q ueue jumpers; they are wealthy; they are illegals'. A Il that language is designed to make people think these are not human beings with feelings and needs like ours. ${ }^{86}$

The above examples demonstrate the government's willingness to portray asylumseekers as 'others': outsiders who are fundamentally different from A ustralians in their values and beliefs; who are attempting to exploit the goodwill of A ustralia and its people; and who potentially pose a direct security threat. These representations are important in reducing empathy for the plight of asylum-seekers domestically and in constructing the government's conception of sovereignty (as the right to exclude) as a legitimate and appropriate conception of sovereignty in this context. Exclusion is achieved discursively, as an act of a sovereign power. The government's willingness and commitment to portraying asylum-seekers in this way also questions the idea of a government compelled to devel op apparently harsh policies towards asylum-seekers by the demands of that population or expectations of international society. If such was the case, there would be little need on the government's part to selectively represent asylum-seekers as others, and particularly misrepresent their behaviour to reinforce this otherness. Once again, acknowledging this point allows us to recognise that there is nothing inevitable about conceiving of sovereignty in such terms, despite the fact that such representations are increasingly apparent in the developed world. 87

\section{Positioning Australia's critics}

The final form of representations addressed here are the government's depictions of critics of its approach to asylum-seekers and associated conception of sovereignty.

85 N eta Crawford, Argument and Change in World Politics (Cambridge: Cambridge U niversity Press, 2002), p. 24.

86 L awrence, Hansard, p. 4423.

87 This trend is particularly evident in Europe. Italy's former Prime M inister Silvio Berlusconi, for example, used similar language to the A ustralian government in justifying hard-line approaches to asylum and immigration by referring to the danger of the $E U$ being 'swamped' by an 'immigration time bomb' (in A lan Travis, 'EU revives Blunkett's asylum camp plan', The Guardian, 20 September 2004, p. 9). H uman rights organisations have also described plans in the European $U$ nion to establish refugee processing camps in northern A frica, which would serve to deny asylum-seekers direct access to developed states in Europe, as 'an abandonment of Europe's historic commitment to refugee protection' (Phil Bloomer et al., 'Scrap asylum camp plans', The Guardian, 22 September 2004, p. 27). As G eddes argues, 'E uropean countries have actually increased both their capacity and willingness to control immigration, especially migration flows defined by state policies as unwanted, such as asylum seekers ..... (A ndrew Geddes, The Politics of Migration and Immigration in Europe (London: Sage, 2003), p. 20). 
This is important to note in understanding that supposedly 'commonsense' accounts of sovereignty are contestable and contested, providing possibilities for progressive change; and that the process of marginalising or silencing these alternative voices is central to the construction of support or resonance for particular conceptions of sovereignty and ethical responsibility. In an important sense, the direct physical exclusion of asylum-seekers was mirrored by the government's attempt to marginalise those voices critical of its asylum-seeker policy. The government even portrayed critics of its policies in similar ways to asylum-seekers themselves: as unconcerned about the realisation or preservation of the rights and values of A ustralians. As noted, the A ustralian government was dismissive of $U$ nited $\mathrm{N}$ ations' criticisms of its policies towards asylum-seekers. For example, in response to a question regarding J ustice Bhagwati's criticisms, F oreign M inister D owner stated that:

I think it is important that the $U$ nited $\mathrm{N}$ ations and its institutions work closely with an advanced liberal democracy like A ustralia - the world's sixth oldest continuously operating democracy - and it is important that the $\mathrm{U}$ nited $\mathrm{N}$ ations examine the facts very carefully when they look into issues like this, rather than just listen to the howling of the political critics of the government or people who are pushing a particular political barrow. 88

A joint media release by $F$ oreign $M$ inister $D$ owner, I mmigration M inister R uddock and Attorney-General Darryl Williams reiterated the government's belief that J ustice Bhagwati's report 'lacks objectivity and misrepresents important aspects of A ustralia's management of immigration detention', adding, 'nothing in J ustice Bhagwati's report is cause to change the view that A ustralia's system of immigration detention is effective . . ${ }^{89} \mathrm{~A}$ gain the day after this media release $\mathrm{F}$ oreign $\mathrm{M}$ inister Downer and Trade $M$ inister Vaile, in a doorstop interview, reiterated:

It is not a professional report. It's a very emotive report... This is a report which is neither comprehensive nor accurate... this sort of activist lobbying of the $U$ nited $N$ ations and the U nited Nations producing these reports which it's done on several occasions, is having the effect of undermining in A ustralia the credibility of the $\mathrm{U}$ nited $\mathrm{N}$ ations. ${ }^{90}$

L ater the same year, after the $U$ nited $N$ ations issued another condemning report, Downer and Ruddock issued another joint media release. This continued the argument that there were 'fundamental flaws in the UN human rights committee system'. The A ustralian government argued that:

The report is particularly disappointing as it has made similar errors to the report of J ustice B hagwati ... Y et again, a human rights body has produced a report misguidedly critical of A ustralia at a time when greater focus on egregious human rights abuses elsewhere in the world would have been more appropriate. ${ }^{91}$

These depictions of international criticism broadly, and U N criticism in particular, can again be viewed as an attempt to silence, marginalise and de-legitimise alternative voices on the sovereignty-human rights relationship in this context. In undermining the extent to which UN criticism might be seen as a legitimate intervention on this issue, the A ustralian government has variously described the $\mathrm{U}$ nited $\mathrm{N}$ ations as listening to the wrong people (domestic critics of the government); idealised; lacking objectivity; misrepresentative; unprofessional; emotive; inaccurate; fundamentally

88 D owner, Hansard, 30 M ay 2002, p. 2773.

89 Downer et al., Joint Media Release F A 109.

90 D owner and Vaile, Doorstop Interview in Brunei.

91 D owner and Ruddock, Joint Media Release FA 184. 
flawed; and misguidedly critical. Such representations both reflect the government's conception of sovereignty and are important in creating conditions in which this conception can predominate over alternative accounts of sovereignty and ethical responsibility.

In responding to domestic criticism, the Australian government has undertaken a similar discursive strategy: of exclusion, condemnation and disparagement. When the Tampa incident began the main Opposition party in the Federal parliament, the A ustralian Labor Party, initially supported the government's policies. Later criticism from the Opposition, however, was met with derision and vilification by the Conservative Government. In a joint press conference on 1 September 2001, H oward and R uddock argued that the 'duty of an opposition on an occasion like this [was] to steadfastly support the national interest'. ${ }^{92}$ The following day, Liberal Party M P Peter Slipper described the Labor Party as 'traitors to Australia. They're not fit to govern.' 93 In parliament D owner said that the Opposition 'do not stand up for the strong protection of A ustralia's borders'. ${ }^{94}$ In 2002, I mmigration M inister R uddock argued that:

The choice for the opposition is now clear. They can either support strong and effective border controls or they can contribute to the weakening of A ustralia's borders and the perils arising from this action. ${ }^{95}$

$\mathrm{H}$ e repeated this exact phrase in parliament nine months later, 96 and again in a slightly modified form in a M edia R elease in J une 2003 when he stated, 'they should have been supporting strong and effective border controls. Instead, they have again demonstrated they are intent on weakening A ustralia's borders'. ${ }^{97}$

The A ustralian Government's depiction of the Opposition was of course influenced by the tenor of debate in an adversarial parliamentary chamber. N evertheless, in seeking to disparage Opposition criticism, the government was able to do two things: attempt to marginalise these voices from the policy process and the construction of sovereignty by portraying them as unconcerned about the nation's core values and interests; and utilise a form of what J anice Bially $\mathrm{M}$ attern describes as 'representational force', which enables the 'user' to 'bluntly, self-interestedly and non-negotiably compel his victim to abide by his version of some contested story'. ${ }^{98}$ The apparent willingness of the major Opposition party to accept the central dimensions of the government's asylum-seeker policy may be viewed in this context, particularly given the extent of public support that the A ustralian government had been instrumental in creating. ${ }^{99}$

92 John Howard and Phillip R uddock, Joint Press Conference, Sydney, 1 September 2001, 〈http://www.pm.gov.au/news/interviews/2001/interview1206.htm〉.

93 Slipper, Interview with Seven Sunrise.

94 Downer, Hansard, 18 J une 2002, p. 3606.

95 Phillip R uddock, House of Representatives Hansard, 20 J une 2002, p. 4019.

96 Ibid., 26 M arch 2003, p. 13586.

97 Phillip Ruddock, Media Release M PS37.2003, 17 J une 2003, 〈http://www.minister.immi.gov.au/ media releases/ruddock media03/r030307.htm〉.

98 Janice Bially M attern, 'The Power Politics of Identity', European Journal of International Relations, 7: 3 (2001), p. 351.

99 A national opinion poll conducted within weeks of the Tampa incident in September 2001 indicated that $77 \%$ of the A ustralian population supported the government's position in denying the Tampa entry to A ustralia, while $71 \%$ supported the government's policy of indefinite detention of asylum-seekers (A C N ielsen poll in Burke, In Fear of Security, p. 323). 
The A ustralian government has variously portrayed an exclusive interpretation of sovereignty as a commonsense response to international norms and domestic responsibilities; has depicted asylum-seekers themselves as different others whose values are inconsistent with those held by Australians; and has disparaged and attempted to de-legitimise alternative voices and associated interpretations of sovereignty. These dynamics are important to recognise in making sense of how certain conceptions of sovereignty and responsibility come to prominence in particular contexts, even while also pointing to possibilities for alternative accounts, with radically different political implications, to emerge.

\section{Inclusion, exclusion and immanent possibility}

For post-structural international relations theorists such as R. B. J. W alker, A ustralia's rejection of the claims of asylum-seekers on the basis of the imperative of preserving its sovereignty is not particularly surprising. Sovereignty in this account is predicated upon exclusion and the inherently dichotomous relationship between inside and outside. ${ }^{100}$ This dichotomy even extends to the point that those inside (citizens) are positioned as in need of being protected from threatening others in the realm of disorder and insecurity outside (asylum-seekers). ${ }^{101} \mathrm{~T}$ his was certainly evident in the (at times farcical) attempts to present asylum-seekers as potential terrorists. But accounts of political autonomy and particularly ethical responsibility are always contested and contestable, and the constructed nature of concepts such as sovereignty means that there always exist immanent possibilities for progressive change.

A range of actors has contested the A ustralian government's image of sovereignty as the right to exclude. International legal analysts and opposition political parties have pointed to the ways in which A ustralia's commitment to various dimensions of the international human rights regime has entailed precisely the refutation of the idea of sovereignty defined as exclusion. ${ }^{102} \mathrm{~A}$ range of critics and minor political parties has directly pointed to the use of rhetorical strategies by the government: in attempting to construct sovereignty as the 'right to exclude'; and (crucially) in attempting to ensure that this conception of sovereignty resonates with the A ustralian population. ${ }^{103} \mathrm{~A}$ nalysts have pointed to the inconsistency of the government's conception of sovereignty in defining asylum-seeker policy with other dimensions of its foreign policy that appear willing to accept increasing global interdependence and even external involvement in domestic politics. ${ }^{104} \mathrm{~F}$ inally, other political representatives have identified (and contested) the ways in which the government has attempted to position opponents of the government's 'impoverished' sovereignty. ${ }^{105}$

\footnotetext{
100 Walker, Inside/Outside.

101 On the positioning of asylum-seekers as security threats, see for example R oxanne D oty, 'Immigration and the Politics of Security', Security Studies, 8 (2/3) (1998/9), pp. 71-93 and J ef H uysmans, 'D efining Social Constructivism: the N ormative D ilemma of W riting Security', Alternatives: Global, Local Political, 27 Special I ssue (2002), pp. 41-62.

102 A ndrew Bartlett, Senate Hansard, 24 September 2001, p. 27693; Pace, Senate Select Committee.

103 Bartlett, Hansard; M aley, 'A sylum-Seekers', pp. 188-90; M cM aster, Asylum Seekers.

104 M aley, 'A sylum-Seekers'.

105 N atasha Stott-D espoja, Senate Hansard, 24 September 2001, p. 27702; Burke, In Fear of Security, pp. 329-31.
} 
Debate has also occurred in relation to directions in asylum-seeker policy. L egal analysts, minor party representatives, NGOs and even former Conservative A ustralian Prime $\mathrm{M}$ inister $\mathrm{M}$ alcolm F raser have pointed to A ustralia's legal and ethical obligations to accept asylum-seekers reaching A ustralia and to treat them more humanely. ${ }^{106}$ Opposition political party representatives have contested the vilification and demonisation of asylum-seekers by the A ustralian government and linked this vilification to the government's political objectives (including electoral victory in 2001). ${ }^{107}$ In the face of concerted and ongoing pressures such as these, as well as A ustralia's stated continued rhetorical commitment to addressing the needs and concerns of asylum-seekers, domestic policy is susceptible to change. Indeed, minor progressive changes in A ustralia's policies in 2004 and 2005108 have largely been the product of such pressures. While prospects for further progressive change under the conservative government should not be overstated, such incremental policy shifts do point to possibilities for further changes in A ustralia's treatment of asylum-seekers and associated conception of sovereignty as the right to exclude.

That contestation of the A ustralian government's conception and representation of sovereignty and their policy choices regarding asylum-seekers has failed to challenge the government's over-arching approach thus far is probably related to two central factors. F irst, the institutional capacity and legitimacy granted to government representatives in defining the 'national interest'. Second, the capacity (and willingness) of the A ustralian government to position marginalised voices as un-A ustralian or unconcerned with the preservation of A ustralian security and national interests. $U$ nder these circumstances, the government has been in a particularly strong position to define the nature of A ustralia's approach and to construct public opinion that it has subsequently claimed it is responding to.

F or some analysts, the A ustralian government's policies and the level of support they enjoy domestically reflect a dark image of A ustralian identity, one defined by racism and fear of the other. ${ }^{109}$ By this account, A ustralia's contemporary approach to asylum-seekers is the latest in a series of racist policies and practices beginning with the dispossession and genocide of its indigenous population and manifesting itself in the White A ustralia Policy in $1901 .{ }^{110} \mathrm{H}$ owever, two points serve to question such a

106 Bob Brown, Senate Hansard, 9 D ecember 2002, p. 7494; Julian Burnside, Refugees: the Tampa Case, 2002, 〈http://www.users.bigpond.com/burnside/tampa.htm〉; A mnesty International A ustralia, Submission to Senate Legal and Constitutional Committee, July 2002, 〈http://www.amnesty.org.au/ resources/submissions〉; M alcolm F raser, 'D ual refugee system shames us', Sydney Morning Herald, 4 October 2002, p. 11.

107 L awrence, Hansard; K irsten Livermore, House of Representatives Hansard, 13 M ay 2003, p. 14013. On the role of the Howard government's approach to asylum-seekers in its election victory in 2001, see D avid M arr and M arian Wilkinson, Dark Victory (Sydney: Allen and U nwin, 2003).

108 In A ugust 2004 the system of temporary protection visas was modified slightly (see fn. 26). In J uly 2005 the federal government responded to pressure from within its own party and released children from mandatory detention (A ndra Jackson, 'L ast children in detention freed today', The Age, 29 J uly 2005, p. 5). A $n$ independent report into the conduct of the D epartment of Immigration, $M$ ulticultural and Indigenous A ffairs (the 'Palmer R eport') in relation to the wrongful detention of an A ustralian citizen also delivered a scathing criticism of the department's procedures and attitudes (M ick Palmer, Inquiry Into the Circumstances of the Immigration Detention of Cornelia Rau (Canberra: Commonwealth of A ustralia, 2005) 〈http://www.minister.immi.gov.au/ media_releases/media05/palmer-report.pdf $\rangle$.

109 Burke, In Fear of Security; M cM aster, Asylum Seekers.

110 Institutionalised with the 1901 'I mmigration R estriction Act', the White A ustralia Policy was designed to prevent access to A ustralia by non-white immigrants. The last vestiges of the policy were only removed in 1973. 
conclusion. First, it does not allow us to understand changes in A ustralia's policies towards immigration and asylum-seekers over time. Second, it serves to obscure the importance of representation, reification and construction of A ustralian identity and national interest, rather tending to present it as a timeless and unchanging account of the A ustralian subject and A ustralian values.

Sovereignty defined as the 'right to exclude' is unambiguously problematic for refugees and asylum-seekers. As we have noted, this conception of sovereignty in the A ustralian context has underpinned policies of detection and interception of asylum-seekers arriving by boat. These policies involve the devotion of significant resources to addressing manifestations rather than causes of a tragic problem: to preventing A ustralians from being forced to confront the suffering of outsiders. Indeed, the acceptance of this conception of sovereignty as legitimate allows for other policies that deny the imperative of redressing the suffering of outsiders as similarly legitimate. Policies of mandatory detention of asylum-seekers, rolling visa systems (that institutionalise uncertainty about the future for asylum-seekers), and an ungenerous quota system cannot be easily separated from the conception of ethical responsibilities inherent in the government's exclusive conception of sovereignty. The A ustralian case serves to demonstrate that through the strategic use of representational practices, and the political will to do so, states can construct the right to exclude as the need to exclude. This points to the inherent limits of statist accounts of ethical responsibility, and raises fundamental questions about the prospects for redressing the suffering of the most vulnerable in global politics. 